$18: 130$

<原 著 $>$

肝粘着性細胞および Kupffer 細胞における tumor necrosis factorの 産生と prostaglandin による制御

\begin{tabular}{|c|c|c|c|c|c|c|}
\hline 則文 & 溝口 & 请紘 & 市川 & 裕三 & 申 & 東桓 \\
\hline ひろ子 & 小林 & 絢三1) & 近藤 & 洋子 & 森澤 & 成司 ${ }^{2}$ \\
\hline 門奈 丈之 & 山本 & 祐夫4) & & & & \\
\hline
\end{tabular}

\begin{abstract}
要 旨：マウスにPropionibacterium acnes (P. acnes) 加熱死菌を静注すると，一週後には肝 臓に単核細胞が浸潤し, 微量の lipopolysaccharide(LPS)を追加静注すると, 厇範な肝細胞壊 死が誘導される.著者らは, この肝細胞障害の誘導にある種の cytokine とアラキドン酸代謝産 物が関与する可能性があることを示唆した。本研究では，正常マウス Kupffer 細胞ならびに $P$. acnes 投与マウスの肝粘着性細胞を分離し， tumor necrosis factor (TNF)の産生とその prostaglandin (PG) に上る制御について検討した。 その結果，LPS 刺激によりKupffer 細胞なら

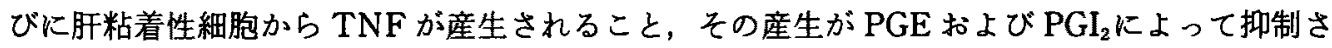
れることが明らかとなった。以上の結果は,肝局所の炎症反応の制御に PG が関与することを示 唆すると同時に, $\mathrm{PGE}$ あるいは $\mathrm{PGI}_{2}$ 投与により, 本モデルの肝障害が著明に軽隇されるといら 著者らの以前の成績の一端を説明でさると考えられる。
\end{abstract}

索引用語： 肝粘着性細胞 Kupffer 細胞 tumor necrosis factor prostaglandin

\section{緒言}

Tumor necrosis factor（以下，TNF）は腫煌細胞 に対して増殖抑制作用や細胞傷害作用を持つ物質とし て発見されだが，遺伝子組み換え型TNFが製造され るにおよんで，種々の生物学的活性を合わ持つこと が明らかにされてきた。すなわち, macrophage や血管 内皮細胞などに対して prostaglandin（以下，PG）の 産生や interleukin（以下，IL) 1 の産生京進させる こど2，好中球に対して，血管内皮に対する付着性を元 進させるこど3, さらには肝細胞に対して、急性相蛋白 の産生を促したり，薬剂代謝の抑制を行ならい，などで ある.このよ5に, TNFは炎症反応の mediator の一 つとして実に多彩な活性を持っておりこの cytokine の肝资への関与について興味が持たれるところであ る.

先に著者らは, Propionibacterium acnes (以下, $P$.
1）大阪市立大学医学部第 3 内科
2) 同 第 1 生化
3）同 公采衛生
4）大阪社会医療センター

〈受付日1989年7月19日〉 acnes) 加熱死菌と lipopolysaccharide (以下, LPS)

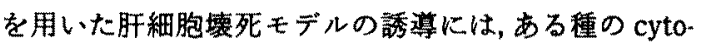
kine とアラキドン酸代謝産物が関与する可能性につ いて示唆した 5.6). また, P. acnes 処理により肝蔵には macrophage を中心とした単核細胞の浸潤がみられ, この肝粘着性細胞の肝細胞障害への関与について検討 を加えている7,8).

本研究では，肝粘着性細胞および正常マウス Kupffer 細胞によるTNF 産生の可能性について検討し，さ らにその PGによる制御機構について解析した。

\section{材料と方法}

\section{1. 材料}

マウスは 6 週龄の雄性 BALB/c マウスおよびC3 $\mathrm{H} / \mathrm{HeJ}$ マウスを用い, クレフ社から購入した。

LPS は Salmonella enteritidis 由来のるのを用い, Difco 社から睛入した。

P. acnes は大阪市立大学医学部細菌学教室から贈与 された。

マウス肝粘着性細胞ならびに Kupffer 細胞を分離 する際に用いた， pronase EはMerk 社から，collagenase type IVは和光純薬から, HEPES (N-2- 
Hydroxyethyl-piperazine- $\mathrm{N}$ '-2-ethanesulfonic acid) はSigma 社から, metrizamide(2-[3-Acetamide-5-Nmethylacetamide-2, 4, 6-tri-iodobenzamide]-2deoxy-D-glucose) は Sigma 社が, EDTA (Ethylenediaminetetraacetic acid, disodium salt) は和光 純薬からそれぞれ睡入した。

Inodomethacinは和光純薬から購入し, $\mathrm{PGE}_{1}$, $\mathrm{PGE}_{2}, \mathrm{PGI}_{2} \mathrm{Na}, \mathrm{PGF}_{2} \alpha$ 抢よび $\mathrm{TXB}_{2}$ は小野薬品中央 研究所から供与された。

Tritiated thymidine (以下, ${ }^{3} \mathrm{H} \cdot \mathrm{TdR}$ ) は NEN 社か ら購入した。

TNF 活性の測定に用いた L-M 細胞は大日本製薬 から供与された。

\section{2. 方法}

1）マウス肝粘着性細胞ならびに Kupffer 細胞の分 離

P. acnes 加熱死菌0.1mg を静注し 1 週後のマウス ならびに正常マウスの腹整内にペントバルビタール1 $\mathrm{mg}$ を注入して麻酔後, 開腹して門脈を䈃出し,カテー テルを捚入した。 このカテーテルからまず $\mathrm{Ca}^{2+}$-free HEPES 加 HBSS 溶 $10 \mathrm{ml}$ を流し，続いて $0.05 \%$ collagenase を含んだ HEPES 加 HBSS 溶液 $10 \mathrm{~m} l$, $0.2 \%$ pronase Eを含んだ HEPES 加 HBSS 溶液 10 $\mathrm{m} l$ を, 順次,それぞれ流速 $3 \mathrm{~m} l / \mathrm{min} て ゙$ 流した。灌流後， 肝䁃を摘出して眼科用バサミで細切し， $0.2 \%$ pronase Eを含んだ HEPES 加 HBSS 溶液 $50 \mathrm{~m} l$ に入れて, 37Cで20分間，振㬈，消化した。末消化物をがーゼで 濾過したのち, 遠心 $\left(400 \mathrm{~g}, 10 \mathrm{~min}, 4{ }^{\circ} \mathrm{C}\right) を 3$ 回繰り 返して cell debrisを取り除いた。得られた cell pellet を $5 \mathrm{ml}$ の HBSS 溶液に浮遊させ，30\%の metr izamide 溶液 $7 \mathrm{~m} l$ と混合して, 遠心 $(1,400 \mathrm{~g}, 15 \mathrm{~min}$, $\left.4^{\circ} \mathrm{C}\right) し た ゙ 9$. 最上相の肝非実質細胞相をとり，洗浄後， $20 \%$ FCS 含有 RPMI 1,640容液に浮遊させ, ブラス チックシャーレ(FALCON 3003)に注入して, $5 \% \mathrm{CO}_{2}$

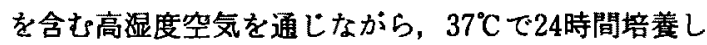
た，培着終了後，ブラスチックシャーレに粘着しない 細胞を取り除いたのち， $4{ }^{\circ} \mathrm{C}$ 漓却した0.02\% EDTA 含有 PBS 㴼液を注入して15分間静置し，ブラスチッ クシャーレから浮遊した細胞を採取して洗浄し，5\% FCS を含んだ RPMI 1640溶液に浮避させて実験に使 用した。尚このようにして採取した細胞の生存率は 98\%以上であり，95\%以上が peroxidase 染色陽性の 細胞であった。

2)肝粘着性細胞ならびに Kupffer 細胞からの

\section{TNF 産生誘導}

$5 \times 10^{5} \mathrm{cell} \mathrm{s} / \mathrm{m} l$ に調整した細胞浮遊液を $\operatorname{lm} l$ ずつ プラスチックプレート（FALCON 3047）に注入した。 各種濃度の LPS (最終濃度, $0 \sim 100 \mu \mathrm{g} / \mathrm{m} l$ ), indomethacin(最終濃度, $\left.0 \sim 10^{-4} \mathrm{M}\right), \mathrm{PG}$ (最終濃度, $0 \sim 100$ $\mathrm{ng} / \mathrm{m} l$ ) 抢よび $\mathrm{TXB}_{2}$ (最終濃度, $0 \sim 100 \mathrm{ng} / \mathrm{m} l$ ) を 同時に添加して24時間培着した。伈停止後，遠心(400 g, $10 \mathrm{~min}, 4{ }^{\circ} \mathrm{C}$ )してその上清を回収し，TNF 活性測 定用のサンプルとした。 サンプルは測定までー80ㄷで 凍結保存した。

3) TNF 活性の測定

細胞培養上清中の TNF 活性の測定は, TNFに高感 受性のマウス肺線維芽細胞由来の細胞株 L-M 細胞を 用いた ${ }^{3} \mathrm{H} \cdot \mathrm{TdR}$ uptake 阻害法にて括こなった ${ }^{10,11)}$ 。す なわち，まず L-M 細胞を5\% FCS 含有 RPMI 1640溶 液にて $5 \times 10^{4} \mathrm{cells} / \mathrm{m} l$ に調整し，100 $\mu l$ ずつ96穴プ レート（FALCON 3047）に注入した。つぎに，上記 の様にして作製したサンプルを1～16倍希釈して100 $\mu l$ ずつブレートに注入した(最終 2－32倍希釈). 注入 後, $37^{\circ} \mathrm{C}, 5 \% \mathrm{CO}_{2}$ の条件下で 44 時間培養し，次いで， 各 well に18.5KBq $(0.5 \mu \mathrm{Ci}) / 10 \mu l$ の $^{3} \mathrm{H}-\mathrm{TdR}$ を添加 してさらに 4 時間培盖した。培蛝終了後, cell harvesterを用いてフィルター上に細胞を集め，細胞への ${ }^{3} \mathrm{H}-\mathrm{TdR}$ の取り込みを液体シンチレーションカウン ターにて測定した，尚，データはサンプルの代わりに 培養液 $100 \mu l$ を添加した場合を control として以下の 式にて計算した。

$\%$ inhibition of ${ }^{3} \mathrm{H}-\mathrm{TdR}$ uptake

$$
=\left(\frac{\text { control dpm-sample dpm }}{\text { control dpm }}\right) \times 100
$$

\section{4) 統計学的検討}

実験データはすべて mean+SEMであらわし，有意 差の検定は Student's testにておこなった。

\section{結 果}

1）肝粘着性細胞による TNF 産生

P. acnes 加熱死菌静注 7 日後の BALB/c マゥス肝 から粘着性細胞を分離し，各種濃度の LPS で刺激した のち，細胞上清中に含まれる TNF 活性を L-M 細胞を 用いたbioassayにて湘定した。この際，サンプルの dilution が assay に影響を及ぼすので，2－32倍まで の各希釈段階で恰討をおこなった，Fig. 1 はLPS 0あ るいは $10 \mu \mathrm{g} / \mathrm{m} l$ 添加24時間後に肝粘着性細胞培着上 清をとり，その各希釈段階に括いて L-M 細胞の ${ }^{3} \mathrm{H}-$ $\mathrm{TdR}$ 取り込みを検討したものである. 低希橎に括いて 


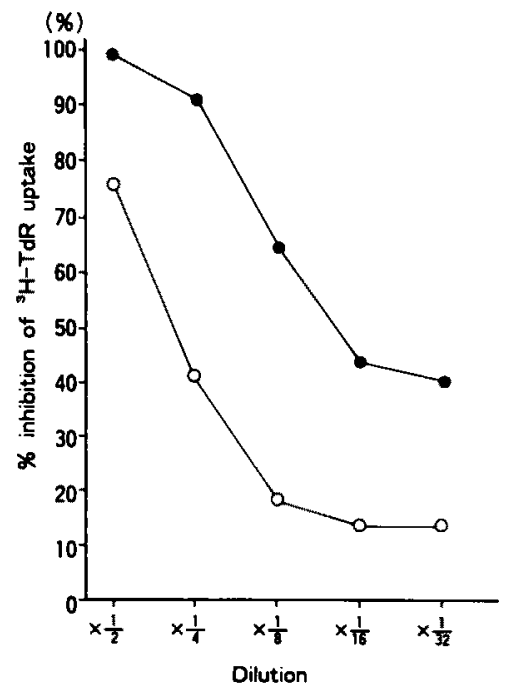

Fig. 1 Effect of dilution on TNF assay was examined. Samples of culture supernatants of liver adherent cells stimulated with or without LPS for 24 hours were diluted with culture medium and used for assay.

- with LPS, O-O : without LPS

は ${ }^{3} \mathrm{H}-\mathrm{TdR}$ 取り込みは極端に阻害され, LPS非添加の 肝粘着性細胞培盖上清を用いた場合でさえ ${ }^{3} \mathrm{H}-\mathrm{TdR} の$ 取り込及は76\%阻害される。一方，高希釈では'ㅏ.TdR 取り込み阻害が抑制される。.以上のことから，肝粘着 性細胞を用いた以下の検討では，4 倍〜16倍希积した 培養上清を assayに用いた。 Fig. 2 に示すように，肝 粘着性細胞からの TNF 産生は添加した LPS の濃度 に依存して增加した。 また, LPSを $10 \mu \mathrm{g} / \mathrm{m} l$ 添加した ときの TNF 産生を経時的に検討すると，LPS 添加 3 時間後に TNF 産生が著明に增加し, 以降, 高濃度を持 続した(Fig. 3)。また，LPS 非添加の状態で培養して も, TNF 産生が認められ，P，acnesによって肝粘着性 細胞がある程度活性化されていることが示唆された。

2）正常マウスKupffer細胞によるTNF産生 BALB/c マウスならびに C3H/HeJ マゥスから Kupffer 細胞を分離し， LPS 刺激下の TNF 産生について 検討した，正常の Kupffer 細胞をLPSで刺敨した場 合の上清中 TNF 活性は各瀑度で肝粘着性細胞に比較 すると低く，このためKupffer 細胞培養上清中の TNF 活性を検討する際は，2 倍希釈した培養上清を assayk用いた．Fig. 4 に示すよ5にLPS非刺激の $\mathrm{BALB} / \mathrm{c}$ マウス Kupffer 細胞培養上清中の TNF 活

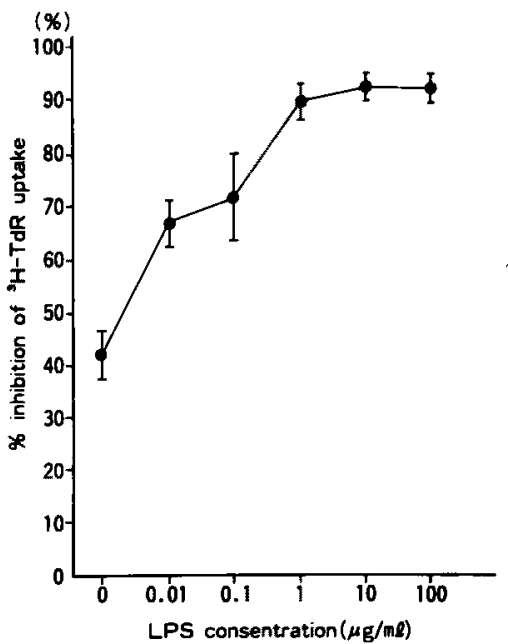

Fig. 2 TNF production by liver adherent cells were examined. Liver adherent cells were stimulated with various concentration of LPS for 24 hours and those supernatants were collected and assayed. Data are shown as mean \pm SEM of 4 experiments.

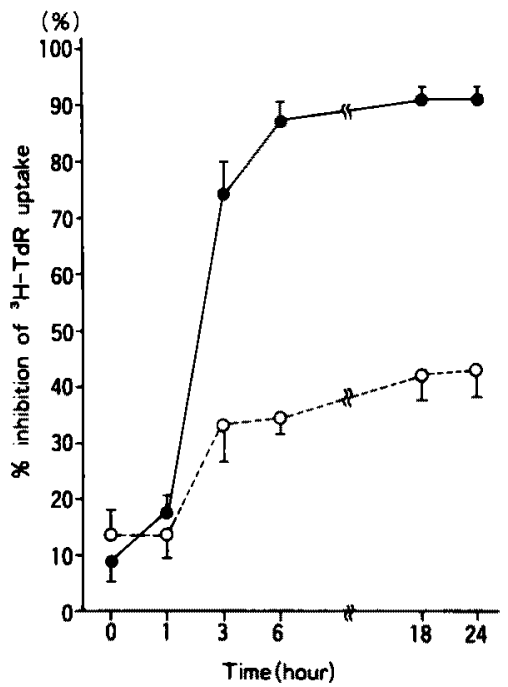

Fig. 3 Kinetics of TNF production by liver adherent cells. Liver adherent cells were stimulated with LPS $(10 \mu \mathrm{g} / \mathrm{m} l)$ at time 0 , and supernatants of time $0,1,3,6,18$ and 24 hours after LPS. addition were collected and assayed.

- : with LPS. O-O : medium only.

性は低值であったが，LPS で刺制を加えるとTNFの 産生增強がみられ LPS の添加灌度が $1 \mu \mathrm{g} / \mathrm{m} l$ 以上で 


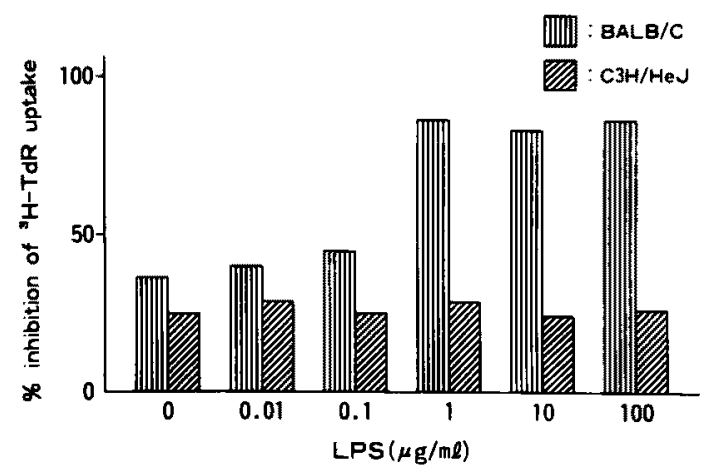

Fig. 4 Production of TNF by Kupffer cells of $\mathrm{BALB} / \mathrm{c}$ or $\mathrm{C} 3 \mathrm{H} / \mathrm{HeJ}$ mouse stimulated with LPS. Mean value of 3 experiments are shown. $x$ $1 / 2$ dilution was used.

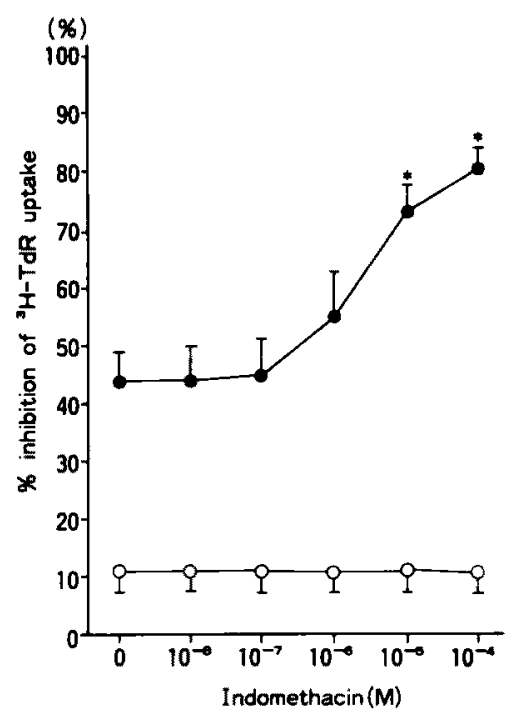

Fig. 5 Effect of indomethacin on TNF production by liver adherent cells. Liver acherent cells simul. taneously added with LPS $(10 \mu \mathrm{g} / \mathrm{m} l)$ and in. domethacin $\left(0-10^{-4} \mathrm{M}\right)$ were cultured 'for 24 hours, and then, collected supernatnts were assayed $(n=4) . \times 1 / 16$ dilution was used.

LPS + indomethacin, $\mathrm{O}-\mathrm{O}$ : medium only, ${ }^{*}: \mathrm{p}<$ 0.01 .

ブラトーに達した。一方, C3H/HeJ マウスの Kupffer 細胞についても同様の険討をおこなった。この場合は LPS の浱度に依存したTNFの産生はみられず，LPS 感受性が欠落していることが示唆された。

2）肝粘着性細胞の TNF 産生に及ぼす indomethacin の影留

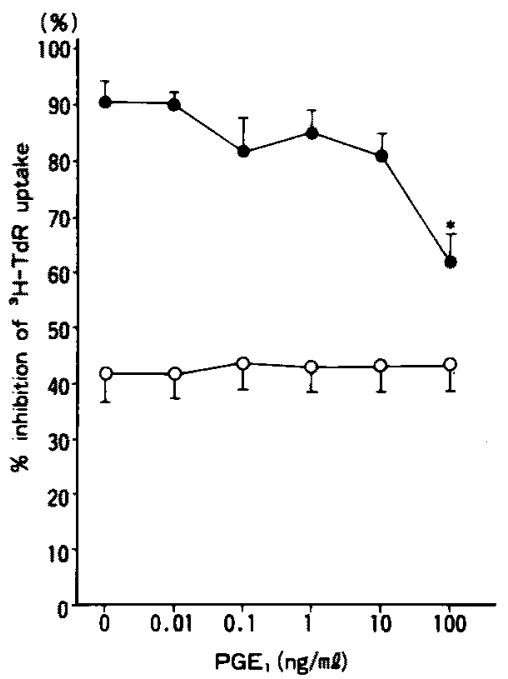

Fig. 6 Effect of $\mathrm{PGE}_{1}$ on TNF production by liver adherent cells. Liver adherent cells simultaneously added with LPS $(10 \mu \mathrm{g} / \mathrm{ml})$ and PGE $_{1}(0$ $100 \mathrm{ng} / \mathrm{m} l$ ) were cultured for 24 hours, and then, collected supernatants were assayed $(n=4) . \times 1 / 4$ dilution were used. - - : LPS + PGE $_{1} . \bigcirc-O$ : medium only. ${ }^{*} ; p<0.01$

Indomethacinは，アラキドン酸からPGならびに TXが生合成される代謝経路の律速䤃素である cyclooxygenase を阻害する。この indomethacinを肝 粘着性細胞の培着液中に $0 \sim 10^{-4} \mathrm{M}$ 濃度添加した場 合に産生される TNF 量の変動について検討した。 Fig. 5 に示すよ 5 に, $10^{-5} \mathrm{M}$ 濃度以上の indomethacinを添加した場合に TNFの産生が増加した。

3）肝粘着性細胞の TNF 産生に及注すPGならび に $\mathrm{TXB}_{2}$ の影響

肝粘着性細胞の培莨液中に最終濃度 $0 \sim 100 \mathrm{ng} / \mathrm{m} l$ の $\mathrm{PGE}_{1}, \mathrm{PGE}_{2}, \mathrm{PGI}_{2} \mathrm{Na}, \mathrm{PGF}_{2} \alpha$ および $\mathrm{TXB}_{2}$ を添加

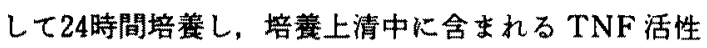
の変動について検討した. Fig. 6〜Fig. 8 に示すよ5 に， $\mathrm{PGE}_{1}$ あるいは $\mathrm{PGE}_{2}$ を最終湶度 $100 \mathrm{ng} / \mathrm{ml}$ 添加し た場合，あるいは $\mathrm{PGI}_{2} \mathrm{Na}$ を最終濃度 $10 \mathrm{ng} / \mathrm{ml}$ ある いは $100 \mathrm{ng} / \mathrm{m} l$ 添加した場合に肝粘着性細胞による TNF産生は有意に揤制された。しかしながら， $\mathrm{PGF}_{2} \alpha$ あるいは TXB 合には TNF 産生量に有意な変化はなかった（Fig. 9， 10).

4）Kupffer 細胞のTNF 産生に及ぼすPGならび に TXB ${ }_{2}$ の影響 


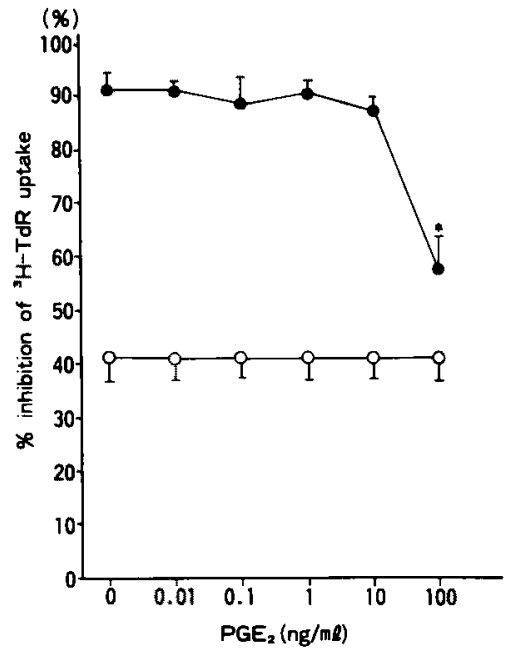

Fig. 7 Effect of $\mathrm{PGE}_{2}$ on TNF production by liver adherent cells. Liver adherent cells simultaneous" ly added with LPS $(10 \mu \mathrm{g} / \mathrm{ml})$ and PGE $_{2}(0-$ $100 \mathrm{ng} / \mathrm{m} l$ ) were cultured for 24 hours, and then, collected supernatants were assayed $(n=4) . \times 1 / 4$ dilution was used. $-\mathrm{LPS}+\mathrm{PGE}_{2}, \mathrm{O}-\mathrm{O}$ : medium only. * $\mathrm{p}<0.01$.

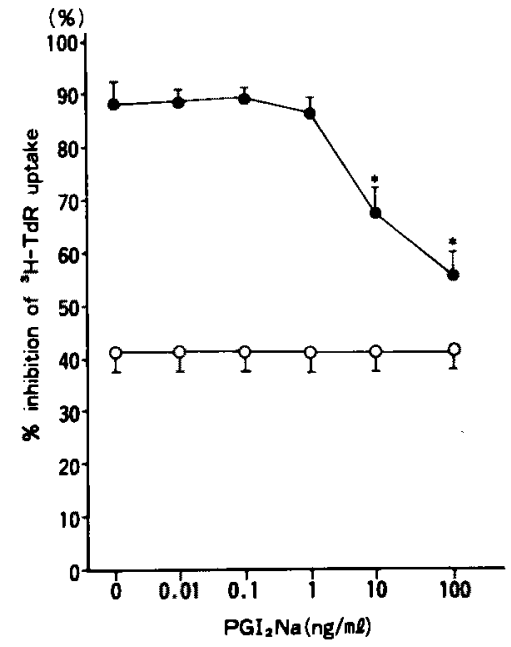

Fig. 8 Effect of $\mathrm{PGI}_{2} \mathrm{Na}$ on TNF production by liver adherent cells. Liver adherent cells simulta. neously added with LPS $(10 \mu \mathrm{g} / \mathrm{m} l)$ and $\mathrm{PGI}_{2} \mathrm{Na}$ were cultured for 24 hours, and then, collected supernatants were assayed $(n=4) . \times 1 / 4$ dilution was used. $-\mathrm{LPS}+\mathrm{PGI}_{2} \mathrm{Na}$. $\mathrm{O}-\mathrm{O}$ : medium only. $* p<0.01$.

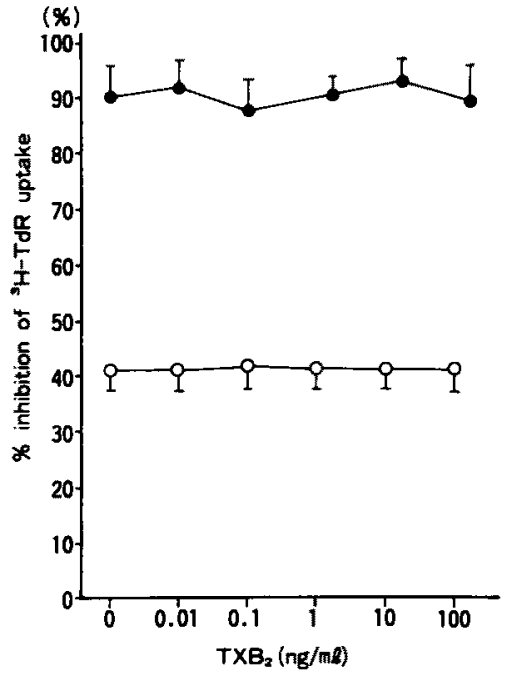

Fig. 9 Effect of $\mathrm{TXB}_{2}$ on TNF production by liver adherent cells. Liver adherent cells simultaneously added with LPS $(10 \mu \mathrm{g} / \mathrm{m} l)$ and $\mathrm{TXB}_{2}(0$ $\sim 100 \mathrm{ng} / \mathrm{m} l$ ) were cultured for 24 hours, and then, collected supernatants were assayed $(n=4) . \times 1 / 4$ $-\times 1 / 16$ dilution was examined and same tendency was shown. $-\mathrm{LPS}+\mathrm{TXB}_{2}, \mathrm{O}-\mathrm{O}$ : medium only.

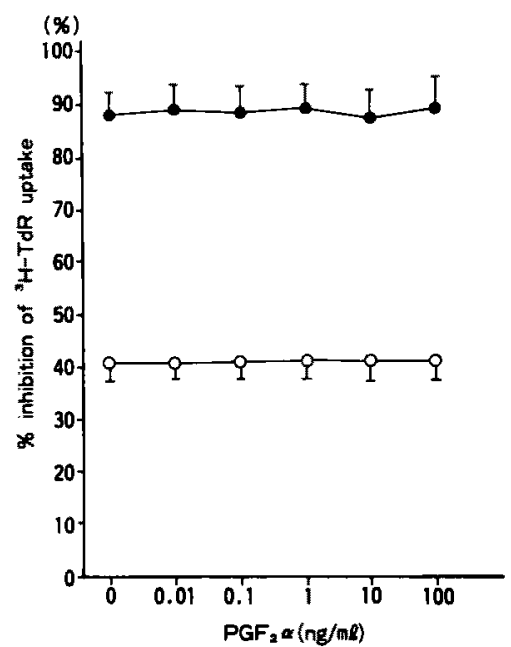

Fig. 10 Effect of $\mathrm{PGF}_{2} \alpha$ on TNF production by liver adherent cells. Liver adherent cells simulta. neously added with LPS $(10 \mu \mathrm{g} / \mathrm{m} l)$ and $\mathrm{PGF}_{2} \alpha$ were cultured for 24 hours, and then, collected supernatants were assayed $(n=4) . \times 1 / 4 \sim \times 1 / 16$ dilution was examined and the same results were shown. - LPS $+\mathrm{PGF}_{z} \alpha, \mathrm{O}-\mathrm{O}:$ medium only. 
Table 1 Effect of PG or $\mathrm{TXB}_{2}$ on TNF production by mouse Kupffer cells stimulated with LPS. All data are shown as mean \pm SEM of 4 experiments.

\begin{tabular}{l|c|c|c|c|c|c}
\hline \multicolumn{1}{r|}{$(\mathrm{ng} / \mathrm{m} l)$} & 0 & 0.01 & 0.1 & 1 & 10 & 100 \\
\hline $\mathrm{PGE}_{1}$ & $86.0 \pm 3.42$ & $85.6 \pm 3.29$ & $82.6 \pm 3.17$ & $81.9 \pm 5.22$ & $69.0 \pm 3.73^{* *}$ & $55.4 \pm 1.67^{* *}$ \\
\hline $\mathrm{PGE}_{2}$ & $87.3 \pm 4.51$ & $87.1 \pm 2.36$ & $85.3 \pm 3.03$ & $84.5 \pm 2.66$ & $74.1 \pm 5.12^{*}$ & $60.7 \pm 2.03^{* *}$ \\
\hline $\mathrm{PGI}_{2}$ & $82.5 \pm 4.20$ & $84.3 \pm 2.79$ & $82.6 \pm 3.91$ & $80.6 \pm 2.98$ & $75.6 \pm 1.22^{*}$ & $71.1 \pm 2.37^{* *}$ \\
\hline $\mathrm{PGF}_{2} \alpha$ & $86.4 \pm 1.73$ & $89.6 \pm 4.11$ & $88.8 \pm 2.66$ & $85.7 \pm 1.39$ & $86.4 \pm 5.16$ & $83.5 \pm 3.17$ \\
\hline $\mathrm{TXB}_{2}$ & $86.1 \pm 6.17$ & $85.7 \pm 5.14$ & $84.8 \pm 3.74$ & $85.0 \pm 2.00$ & $87.8 \pm 6.13$ & $89.3 \pm 4.59$ \\
\hline$* \mathrm{p}<0.05, * * \mathrm{p}<0.01$ & \multicolumn{5}{c}{ (\% inhibition of ${ }^{*} \mathrm{H}-\mathrm{TdR}$ uptake) }
\end{tabular}

正常の BALB/c マウスKupffer 細胞からLPS 刺 激下に産生されるTNF量に及ぼすPGならびに $\mathrm{TXB}_{2}$ の影響について検討した。その結果, Table 1 に 示すよ 5に, $\mathrm{PGE}_{1} ， \mathrm{PGE}_{2}$ 招よび $\mathrm{PGI}_{2}$ が Kupffer 細胞 からの TNF 産生を抑制することが明らかとなった。 さらに，肝粘着性細胞の TNF 産生を抑制するよりる 低い濃度で，抑制効果がみられた， $\mathrm{PGF}_{2} \alpha$ 於よび $\mathrm{TXB}_{2}$ は Kupffer 細胞の TNF 産生には影響を及淿さ なかった。

\section{考察}

P. acnes 加熱死菌静注 7 日後に, 肝蔵から粘着性細 胞を分離し, LPSで刺激すると，LPS の添加濃度に依 存してTNFの産生が增強された（Fig. 2)。亨た， TNF の産生は, LPS 添加 3 時間後から急激に增加す ることが認められた (Fig. 3)。そこで，この TNF 産 生の調節機構を解明するために，今回は，PGに着目 し，ず，PG 産生を阻害する indomethacinの影響に ついて検討した. IndomethacinはPG 扰よびTX 合 成酵素の一つである cyclooxygenase を特翼的に阻害

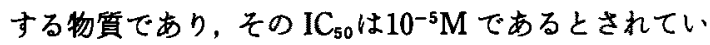
る.その結果, indomethacin 添加により肝粘着性細胞 によるTNF 産生が増強した（Fig. 5)，これはPG 類 のなかで，TNF 産生に対して抑制的に作用する物質 を粘着性細胞が産生することを示唆した.そこで, 個々 の PG LPSを添加すると同時に加えて, TNF 産生 に及ぼす影響について検討した。その結果， $\mathrm{PGE}_{1}$ ， $\mathrm{PGE}_{2} お$ よび $\mathrm{PGI}_{2} \mathrm{Na}$ が肝粘着性細胞による $\mathrm{TNF}$ 産 生を抑制した（Fig. 6〜8)，しかしながら， $\mathrm{PGF}_{2} \alpha$ な らびに TXB (Fig. 9, 10).

また，正常マウス Kupffer 細胞の LPS 剌激による TNF 産生についても唋討した。 その結果, BALB/c マ
ウス Kupffer 細胞からは LPS 刺激下に TNF 産生が みられた。しかし，C3H/HeJ マゥスKupffer 細胞から のTNF産生はみられなかった，そこで, BALB/c マ ウス Kupffer 細胞からの TNF 生に及ぼすPGお び TXB ${ }_{2}$ の影響についても検討を加えた。その結果， 肝粘着性細胞の場合と同様に $\mathrm{PGE}_{1}, \mathrm{PGE}_{2}$ および $\mathrm{PGI}_{2}$ が Kupffer 細胞からの TNF 産生を抑制した。し

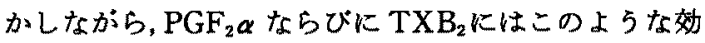
果はみられなかった (Table 1).

PGおよびTX は炎症の mediator として, 血管の払 張や透過性九進, 平滑筋収縮ならびに血小板凝集に関 与することが明らかにされている(2)，さらに $\mathrm{PG}$ ，とく にPGEは免疫反応の regulator として作用すること が知られており， $\mathrm{T}$ 細胞機能の抑制，抗体産生の抑制, ならびに suppressor macrophage の誘導をおこなう ことなどがしられている ${ }^{13)}$.また，in vitroです癌細胞 を移植された動物の生存率が, indomethacinを投与す ることで改善することから，PG 類のなかに危疫抑制 的に作用する物質が存在することが示唆されている。 また，IL 1 やNFなどの cytokineの産生に対して PGが調節的な作用をむつことが示晙されており，局 所の feed-back mechanismを考えるうえでPGは中 心的な牦きをしている可能性がある 14,15).

一方，主として monocyte-macrophage 系細胞が産 生する生理活性物質のなかに TNFがある. TNFは Carswell らによって BCG 感染マウスをエンドトキシ ン処理した血清に見いだされる物質として発見され た1もので, Meth Aサルューマ, EL-4白血病やP815 肥満細胞畽等に対して強い殺細胞活性を示し, in vivo に移植した腫場に出血性の壊死を引き起こすことが報 告されている゙．さらに遗层子組み换え型のTNF が合 成されるに及んで 
以外の生物活性が次々と明らかにされてきた。例えば， 好中球はTNFによって活性化され，殺菌作用， $\mathrm{O}_{2}-$ $\mathrm{H}_{2} \mathrm{O}_{2}$ 等のラジカル産生の増強，さらに血管内皮細胞一 の付着の六進などがおこる゙．また，TNFは血管内皮 細胞に対して直接的に細胞障害的に作用したり，血管 内皮細胞による IL 1産生を助長することが知られて2， これらが腫瘍を出血性壊死に䢘く原因であると考えら れている。また，TNFは肝細胞に作用して、いわゆる acute-phase reactants の産生を誘導することも知ら れている゙.さらに, TNFが種々の細胞のフラキドン 酸代謝に影䇾を及ばすことも知られており，macrophage，破骨細胞の $\mathrm{PGE}_{2}$ 産生を促進することが報告 されている。また，著者らは，TNFがマウス Kupffer 細胞の $\mathrm{PGE}_{2}$ 合成を增強することを報告している

TNF の合成と遊離については既に詳しく険討され ており，LPS 暴露をらけた macrophage からは20〜30 分以内に TNFの遊離がみられること, mRNA レベル のビークは 2〜3時間後にみられること, TNF 合成 は 4ー6 時間で終了することなどが報告されてい る(19). 今回の著者らの検討もこれによく一致し，肝 macrophage $の$ TNF 合成は LPS 添加 3 時間目に急 激に上昇し，6時間後には既にビークに達していた。 また，TNFの合成とほぼ同様の動きを示すIL 1 の合 成は, macrophage がガラスやブラスチック面に付着 するだけでる誘導されることが報告されているので， 今回 LPS 非添加時にる みられた TNF 活性も同様の 機序が考えられ，刺激を受けないKupffer 細胞や肝粘 着性細胞が spontaneousにTNFを産生するかどう かについてはさらに種なの条件下で倹討せねばならな W.

TNF 合成を制御する物質としては glucocorticoid hormonesについて詳しく検討され glucocorticoids を前投与された動物で LPSショックによる死亡率 が改善することや，逆に adrenalectomyを5けた動物 ではLPSに対する感受性が高まることが報告されて いる20). しかし，他の制御機構についての報告は少な く, $\mathrm{PGE}_{1}, \mathrm{PGE}_{2}$ よび $\mathrm{PGI}_{2} \mathrm{Na}$ が $\mathrm{TNF}$ の産生を制 御している可能性を示唆した今回のデータは macrophage が生合成する物質間の feedback mechanism である可能性があり今後さらに検討をすすめる予定で ある。

さて，マウスにP. acnes 加熱死菌を静注すると，一 週後には肝脄に macrophageを中心とした単核細胞 が増加し、さらに微量の LPSを追加することで出血を
伴った広範な肝細胞壊死が惹起されることから，增加 した macrophage がこの病態形成に中心的な働きを していることが推測される8,9. しかし，その機序は現 在のところ不明であり，多角的なフプローチが必要で ある。ささきに清口らが報告しているように，本モデル に打ける生存率，生化学データ，ならびに組織学的変 化が $\mathrm{PGE}$ や $\mathrm{PGI}_{2}$ を前投与された動物では著明に改

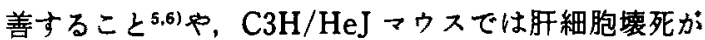
惹起されないことから，今回の in vitroでの検討と合 わせると，TNFが本モデルにおける肝障害に何らか の関与をすることが推測される、TNFが直接的に肝 細胞を傷害するのか，炎症の mediator として肝炎を 修飾するのみなのか，については今後の検討を待たね ばならない。

\section{結 論}

P. acnes 投与により肝臟に増加した粘着性細胞，な らびに, Kupffer 細胞が TNF を産生した。またっこの $\mathrm{TNF}$ 産生は $\mathrm{PGE}_{1}, \mathrm{PGE}_{2}$ および $\mathrm{PGI}_{2} \mathrm{Na}$ により抑制 される可能性が示唆された。

$$
\text { 女 韵 }
$$

1) Carswell EA, Old LJ, Kassel RL, et al: An endotoxin-induced serum factor causes necrosis of tumors. Proc Natl Acad Sci USA 72: 3666 $-3670,1975$

2) Charles AD, Joseph GC, Sheldon MW, et al: Tumor necrosis factor (cahectin) is an endogenous pyrogen and induces production of interleukin 1. J Exp Med 163 : 1433-1450, 1986

3) Gamble JR, Harlan JM, Klebanoff SJ, et al: Stimulation of the adherence of neutrophils to umbilical vein endothelium by human recombinant tumor necrosis factor. Proc Natl Acad Sci USA 82 : 8667-8671, 1985

4) Perlmutter DH, Dinarello CA, Punsal PI, et al : Cachectin/Tumor necrosis factor regulates he. patic acute-phase gene expression. J Clin Invest 78 : 1349-1354, 1986

5) Mizoguchi $Y$, Tsutsui H, Miyajima K, et al: The protective effect of prostaglandin $E_{1}$ in an experimental massive hepatic cell necrosis model. Hepatology $7: 1184-1188,1987$

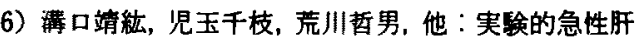
不全モデルの生存率に及ばす prostaglandinの影 霎. 日消誌 $84: 2558-2562,1987$

7) Tsutsui $H$, Mizoguchi $Y, Y$ amamoto $S$, et al: 
Studies on experimentally-induced acute hepatic failure : Possible involvement of activated liver adherent cells $I n$ : Cells of the Hepatic Sinusoid, Vol.1, Edited by Kirn A, Knock DL and Wisse E. Kupffer Cell Foundation, The Netherlands, 1986, p307-313

8）商井ひろ子：実験的に㴽道した急性肝不全マウス の免疫学的研究 実験的急性肝不全の誘導とその 肝細胞障害機構について. 肝臓 $26: 1488-1444$, 1985

9) Knock DL, Sleyster ECH : Separation of Kupffer and endothelial cells of the rat liver by centrifugal elutriation. Exp Cell Res 99:444 $-449,1976$

10) Ruff MR, Gifford GE: Rabbit tumor necrosis factor: Mechanism of action. Infection and Immunity $31: 380-385,1981$

11) Bloksma $N$, Shetters TP, Figdor $C$, et al: In vitro anti-tumor activity of tumor necrosis serum. Int J Immunopharmac 2 : 95-100, 1980

12) Williams TJ, Peck MI: Role of prostaglandin-mediated vasodilation in inflammation. Nature 270 : 530-538, 1977

13) Goodwin JS, Webb DR: Regulation of the immun response by prostaglandins. Clin Immunol Immunopathol $15: 106-122,1980$

14) Renz H, Gong JH, Schmidt A, et al: Release of tumor necrosis factor- $\alpha$ from macrophages. Enhancement and suppression are dose- dependently reggulated by prostaglandin $E_{2}$ and cyclic nucleotides. J Immunol 141: 2388 $-2393,1988$

15) Brandwein SR: Regulation of interleukin 1 production by mouse peritoneal macrophages. Effect of arachidonic acid metabolites, cyclic nucleotides, and interferons. J Biol Chem 261 : $8624-8632,1986$

16) Shirai $T$, Yamaguchi $H$, Ito $H$, et al : Cloning and expression in Escherichia coli of the gene for human tumor necrosis factor. Nature 313 : 803-806, 1985

17) Pennica D, Nedwin GE, Hayflic JS, et al: Human tumor necrosis factor: precursor structure, expression and homology to lymphotoxin. Nature 312: 724-729, 1984

18）河田則文，久保井広志，申東桓，他：一ウ Kupffer 細胞の prostaglandin $E_{2}$ 産生に及ぼす tumor necrosis factor $\alpha$ 及び interleukin $1 \alpha$ の 影響。肝臓，印刷中

19) Gifford GE, Lohmann-Mattes ML: Requirement for the continual presence of lipopolysaccharide for production of tumor necrosis factor by thioglycolate-induced peritoneal murine macrophages. Int J Cancer 38 : 135-137, 1986

20) Beutler B, Cerami A: Cachectin and tumor necrosis factor as two sides of the same biological coin. Nature $320: 584-588,1986$ 


\title{
Production of tumor necrosis factor by liver adherent cells and its regulation with prostaglandins
}

\author{
Norifumi Kawada, Yasuhiro Mizoguchi, Yuzo IchIKawa, Toukan Shin, Hiroko TsuTsuI, \\ Kenzo Kobayashi*, Hiroko Kondou, Seiji MoRISAWA**, \\ Takeyuki MonNA*** and Sukeo YAMAMOTo*****
}

When the heat-killed Propionibacterium acnes ( $P$. acnes) was injected into mouse through tail vein, macrophages including Kupffer cells accumulate in the liver reaching its maximum 7 days later. To study the function of these liver adherent cells, production of tumor necrosis factor (TNF) and its regulation by prostaglandins (PGs) were investigated in $\mathrm{BALB} / \mathrm{c}$ mouse and $\mathrm{C} 3 \mathrm{H} / \mathrm{HeJ}$ mouse. As a result, in BALB/c mouse, $P$. acnes-elicited liver adherent cells and Kupffer cells produced TNF by stimulating with endotoxin lipopolysaccharide in dose-dependent manner, but in C3H/HeJ mouse, not. When, in BALB/c mouse, these liver adherent cells and Kupffer cells were treated with PGE and PGI, production of TNF was significantlly reduced. These results suggested that TNF may play a role in the induction of acute hepatic cell necrosis model, and inhibition of TNF production by liver adherent cells and Kupffer cells possibly suppress liver injury in this model.

* The Third Department of Internal Medicine, Osaka City University Medical School (Osaka)

** The First Department of Biochemistry, Osaka City University Medical School (Osaka)

*** Department of Public Health, Osaka City University Medical School (Osaka)

**** The Osaka Socio-Medical Center Hospital (Osaka) 